\title{
Mergers and Acquisitions on Financial Performance of Commercial Banks In Rwanda: Case of I\&M Bank Ecobank And BPR Atlas Mara
}

\author{
MAZIMPAKA Pierre Claver ${ }^{1}$ Dr.Claude RUSIBANA $(\mathbf{P h D})^{2}$ \\ ${ }^{1}$ MBA Student, Mount Kenya University, Rwanda \\ ${ }^{2}$ Senior Lecturer, Mount Kenya University, Rwanda \\ DOI: 10.29322/IJSRP.11.05.2021.p11314 \\ http://dx.doi.org/10.29322/IJSRP.11.05.2021.p11314
}

\begin{abstract}
Most of the banks in Rwanda have undergone through the process of Merger and/or Acquisition in the recent past. The general objective of this study was to assess the effects of business merger and acquisition on bank financial performance in Rwanda. This study aimed to assess the factors that lead the merger and acquisitions in commercial banks in Rwanda, to assess the factors that determine the performance of commercial banks in Rwanda, to determine the relationship between merger and acquisition and the financial performance of banks in Rwanda. This study is significant to bankers, business developers and academic researchers. The study targeted three banks in Rwanda namely the BPR Atlas Mara, I\&M Bank and Ecobank. These banks had 1724 employees countrywide composed the target population. Due to the large number of employee's target, the researcher targeted a number of 750 employees from three selected banks. The study used Slovin's formula to get a sample size of 88 respondents on which $96 \%$ have responded. As findings, the study indicates five main factors that lead the M\&A in financial institutions include; providing variety of products and services to clients, cost efficiency, fulfilling capital requirement, asset acquisition and economies of scale. The merger and acquisitions can increase the performance of commercial banks in terms of CAR, ROA, ROE and ROI. The regression showed that the factors that led to merger and acquisitions contribute of $42 \%$ to the improvement of CAR, $48 \%$ to the improvement of ROA, $47 \%$ to the ROE and $53 \%$ to the ROI. It was recommended that commercial banks should continue to embrace M\&A in order to improve the financial performance. This should be recommended to be undertaken by small banks in order to increase their competitiveness in the market. Banks should increase on their capital structure in order to operate effectively and efficiently, and strive to efficiently management of assets at their disposal at a minimum cost. This will increase bank's profitability and encourage the shareholder to invest more in the bank. For further researchers, they should focus on Investigation on effect of Intellectual Capital on financial performance selected Commercial banks. The researchers should also conduct a new research on effect of technology innovation on financial performance of selected commercial banks.
\end{abstract}

Keywords: mergers, acquisitions, financial performance, commercial bank

\subsection{Introduction}

Global markets have continuously experienced increased in merger and combination of businesses. The concept of Mergers is a situation where for many strategic and economic reasons, two or more companies or indeed, organizations come together to form a larger company (Akben-Selcuk, 2011). Acquisition refers to is an action in which one company purchases most or all of another company's shares to gain control of the acquired company

Historically, mergers and acquisitions have been most pronounced in the United States and the United Kingdom. Within the merger activities, bank mergers happened in the fourth wave from 1980 to 1989, which originated from the US. Since the long-standing geographical restrictions of banking were revoked in the US in 1994 (Riegle-Neal Interstate Banking and Branch Efficiency), bank merger activities were popular within the banking industry. Europe caught up this trend due to the globalization and borderless 
economy. During the 1990s, the volume and number of merger and acquisitions increased in the EU (Liargovas \& Repousis, 2011). Under the circumstances, bank merger activities became a global and borderless activity.

Most companies then were merging for monopoly reasons. That is, to say that two or more companies merged then, in order to create bigger company that would dominate the share of the market (Kumshe, Kwazhi \& Imam, 2015). The main motivation behind merger and combination is to maximize shareholders value. Bashir, Sajid, \& Sheikh (2011) having considered its significance note that mergers and combination should be taken seriously as an instrument for enhancing size and development of the bank.

There are different ways of measuring financial performance, but all measures should be taken in aggregation. Most growing businesses ultimately target increased profits which make it important to know how to measure profitability (Mustafa, 2014). The key standard measures of financial performance include: gross profit margin which measures how much money an organization has made after direct costs of sales have been taken into account; operating margin lies between the gross and net measures of profitability after overheads are taken into account before interest and tax payments known as the EBIT (earnings before interest and taxes) margin. Net profit margin is a much narrower measure of profits, as it takes all costs into account, not just direct ones. All overheads, as well as interest and tax payments, are included in the profit calculation (Muhammad, 2011)

There are several studies which have been conducted about the effects of merger and acquisition of business in various parts of the world and how it affects the performance of the acquiring companies. Some of the leading banks in America such as Citigroup (NYSE:C), Wells Fargo (NYSE: WFC), JPMorgan Chase (NYSE: JPM), and Bank of America were actually 35 separate companies in 1990. Citigroup was formed from two major financial corporations: Citicorp and Travelers Group, which merged in 1998 in a $\$ 140$ billion deal. At the time, it was the largest corporate combination in history. Wells Fargo had some big deals in the '90s, completing a merger with First Interstate in 1996 valued at $\$ 11.3$ billion and another merger with Norwest in 1998 worth $\$ 31.7$ billion. JPMorgan Chase, as its name implies, arrived at its current form from the 2000 purchase of J.P. Morgan by Chase Manhattan Bank for approximately $\$ 30$ billion in stock. Then, in 2004 the bank purchased Bank One in a \$58 billion deal that resulted in JPMorgan becoming the second largest bank in the U.S. at the time. Bank of America was perhaps the busiest of the four in terms of big deals. First, the 1998 merger of Bank America and Nations Bank created the entity known as Bank of America, with assets of $\$ 570$ billion and an extensive network of 4,800 branches. Then in the mid-2000s, Bank of America completed one major deal every year. Between 2004 and 2007, the bank bought FleetBoston Financial for $\$ 47$ billion, credit card giant MBNA for $\$ 35$ billion, U.S. Trust for $\$ 3.3$ billion, and LaSalle Bank for \$21 billion (Frankel, 2015).

There are several studies which have been conducted about the effects of merger and acquisition of business in various parts of the world and how it affects the performance of the acquiring companies. In Africa, Access Bank Plc in December 2018 announced that it has merged with another lender Diamond Bank Plc. In Rwanda, there have been a number of banks, which have been merged and acquired by international financial institutions. BPR Atlas Mara, I \& M Bank and ECOBANK are top three selected banks in Rwanda which have recently underwent merger and acquisition. ECOBANK acquired BCDI in 2007 in a deal of 11.6 million and has taken the full control of the Bank. In the year 2012, I\&M BANK acquired BCR and took the majority of shares of $80 \%$. Recently, Atlas 
Mara acquired and merged BPR and BRD and has invested \$31.260 million (about Rwf 28, 200.00 billion) into the bank and hold a majority stake in the financial institution of about 62\%, the deal was concluded in 2016.

According to BNR report 2006, the performance of the bank sector in Rwanda was amazing where the consolidated increase of Net Profit was 14\%. This was different with the BCDI's performance, which had the negative net profit (BCDI financial statement 2006). A slight net profit was realized by BCR, where BNR report 2011 showed an increase of net profit to $42 \%$ while BCR Bank made a loss (BCR financial statement 2006). For BPR, it was the same issue. As indicated by BNR report 2015 the net profit increase of $36 \%$ while BPR made a loss. From the above different BNR report, same Banks were making amazing net profits while other where making losses. This indicates that, before merger and acquisition, these banks said above had the same issue of financial performance. The problem was to know if the M\&A is a good strategy to improve the Financial Performance of Commercial Bank in Rwanda. However, there is no empirical evidence in Rwandan context which shows the effects of merger and acquisition on bank financial performance. This research analyzed the effect of merger and acquisition on commercial banks in Rwanda.The general objective of this study is to assess the effects of business merger and acquisition on bank financial performance in Rwanda. Thee specific objective of this study were the following :

i. To assess the factors that lead the merger and acquisition in commercial banks in Rwanda

ii. To assess the factors that determine the performance of commercial banks in Rwanda

iii. To determine the relationship between merger and acquisition and the financial performance of banks in Rwanda

\section{LITERATURE REVIEW}

\subsection{Theoretical literature}

Over the years, scholars have put forward theoretical arguments both in support and against the adoption of merger and acquisition as a veritable strategy for performance enhancement in business organizations. This study is review different studies related to the study in question.

\subsubsection{The role of mergers and acquisitions on the performance of financial institutions}

Mergers and acquisitions are defined according to Kithitu (2012) as a means of establishing the organizational purpose in terms of its long-term objectives, that includes its resource allocations and programs, this is usually done in order to maximize its long-term profitability credentials, while the author continues to envisage mergers and acquisitions as a process that usually happen two organizations of almost equal size come together to form one company hence, this happens on friendly grounds when two organizations in this case two banks restructure their assets and even resources by pulling together their existing markets, technology, products and management with a core objective of strengthening all the possible opportunities hence leveraging their competencies and capabilities to increase shareholder's value.

Kithitu, (2012) examines the role of mergers and acquisitions on the commercial banks by undertaking a ratio analysis of major commercial banks, while this study indicated improved performance in many scenarios due to mergers and acquisitions, this impact 
wasn't significant as a result of little improvement in profitability and efficiency in the short-run, though greater impact was envisaged on the cost efficiency in the long-run as banks crave for greater competitiveness through bigger market share, accumulating more portfolios by reducing the entire business risks, new market opportunities, large scale economies, increasing shareholder's value and management efficiency that all come with mergers and acquisitions.

Terraza, (2015) stated that while the role of mergers and acquisitions continue to show mixed signals in this literature, many of them continue to happen in financial institutions, despite the fact that, these mergers and acquisitions portray no significant differences after merging and before merging prospects as financial characteristics seem to be almost the same, but only considering the financial synergies and at times growth, these mergers and acquisitions in the financial sector continue to prevail with the core hopes of profitability, shareholder's value and greater bank's efficiency, this is further linked to day's globalization and first changing market environment where mergers are associated with benefits of scale and scope as the accounting ratios.

used to determine the profitability clearly indicates where key profitability performance indicators of ROE, ROA and EPS were used to examine the role of these acquisitions and mergers on both post-merger and pre-merger and acquisitions of financial institutions with the core findings elaborating that, these mergers and acquisitions fail to create value on an average of two-thirds of medium and larger merger deals an existing literature on these financial sector acquisitions indicate in the findings of (Kithitu, 2012).

In connection to the above, the author further emphasizes that, the mergers in the financial sector usually registers gains of mergers in terms of share-price that portrays good positive returns prior to the announcements of mergers and less portfolios immediately after merger period.

The literature also indicate that, a considerable and positive cumulative average abnormal returns of mergers and acquisitions are evidenced in a period of ten days prior to merger announcements, where significant results are received upon the announcement of diversifying and horizontal bank deals, it is however noted that these results have no greater impact and eventually does not create wealth by the merged banks as the operating performance of these mergers doesn't increase at all (Liargovas, 2011).

\subsubsection{Impact of mergers on profitability of acquiring companies}

Available evidence from the literature shows that, profitability declines after mergers, it however indicate that mergers are successful by showing only positive indicators on size and leverage, where by the size and relative interest coverage ratio improved significantly after the mergers as this supports the growth maximization theory of mergers, but this does not support the performance theory as profitability and liquidity tend to decline due to mergers, most profoundly is the decline in profitability and yet liquidity indicating insignificant decline. The decline in profitability is manifested in the current ratio, size and even the debt equity ratio that possess a negative impact on profitability as only interest coverage ratio contributing towards profitability especially in the future (Ramakrishnan, 2010). This decline in profitability is forecasted for a period of five years after merger and therefore no significant improvement in performance is expected in the short-run, while this may not only be attributed to the merger characteristics only but even the economy itself, though in the future prospects of improvements in profitability is expected as interest coverage predicts profitability than the debt equity ratio.

\subsubsection{Employee satisfaction as a result of mergers and acquisitions.}

In the recent years, due to high competition that has attracted mergers and acquisitions in many leading firms, corporations and financial institutions, the issue of employee satisfaction and benefits due to mergers and acquisitions have become a key contentious issue among many merging companies as employee benefit component and its compensation programs are very critical sources of the economic security of the employees, while employees expect high rates of protection from the employer especially on the risks of illness, disability, death and at times loss of income at retirement, these benefits are greatly taken as a matter of employer's own choice, most research findings indicate that as a result of mergers and acquisitions, many firms tend to experience termination, 
reduction or substantial changes in employee benefits hence affecting diversely on the employee satisfaction to these corporate mergers, this is well supported by the argument that, employee benefits should more be looked at as more of a clinical situation than a mere analytical one (Uwizeye, 2016).

\subsection{Empirical literature}

\subsubsection{Effects of M\&A and stakeholder interests}

The researcher further articulates how considerable debate has been in place regarding stakeholders and stockholders after mergers and acquisitions, where employee morale is the core element of every success in mergers and acquisitions, though adjusting psychological and divergent organizational structures, climates and values remain critical in effective implementation of mergers and acquisitions due to heavy workload as this increases with M\&A, eminent downsizing especially on managerial and professional employees impose a higher risk due to mergers and acquisitions as these jobs are only distributed among lower level employees.

Although the employees feel a sense of relief when merging is complete, this feeling usually fades as downsizing and high cost cutting measures follow, this negative environment that often results in higher employee turnover brings anger and anguish among affected employees and those remaining feel the sense of guilt, anger and though some feel a great sense of relief, the ultimate sense of future dismissals remain alive in their work activities, and therefore the possibility of a better peaceful and positive work relationships among employees after an M\&A grows narrower which affects their productivity and hence negatively impacting the profitability of the merged company.

\subsubsection{Effects of merger and acquisition on providing variety of products \& service to clients}

Sufian \& Habibullah (2010) observes Malaysian banking sector on the basis of their technical efficiency after merger and acquisition. This led to the development of new and innovative ways of delivering bank products to the clients and introduction of new products and services in banking sector. The study found a higher mean technical efficiency level when they compare it with the pre-merger period. Mishra \& Chandra (2010) examined Indian pharmaceutical firms' performance with respect to M\&A. They were of the view that M\&A have no significant impact on at firm's probability in the long run and this is due to the resultant X-inefficiency and entry of new firms into the market.

Obaid-ullah, Sabeeh-ullah and Usman (2010) investigated the effects of mergers on the financial performance of Atlas Investment and Al-Faysal Investment Bank Ltd from Pakistan. Study employed three financial measures; profitability and earning, capital adequacy and solvency. It found that for Faysal bank limited average improvement is recorded in the post-merger period. It is concluded that in post-merger period of both sampled banks improved their financial performance. The researchers concluded that M\&A is a good strategy to increase the performance of the bank. Merger increase the financial performance due to improved attention to business, improved management, better credit assessment, and easy access to the new and expensive technology indicate the quantitative findings of the research.

\subsubsection{Effects of merger and acquisition on cost efficiency}

Mwangi (2014) studied the impact of mergers in banking industry on efficiency and profitability considering both the domestic and cross border mergers. It discussed the cost and profit efficiency analysis of 33 banks to bank mergers which shows that the most of the domestic mergers improves the cost efficiency and little improvement of profit efficiency whereas little improvement in the profit efficiency and no improvement in the cost of efficiency in the cross border mergers indicate the quantitative findings of the research no statistical findings 
Ramakrishnan (2010) focused on the efficiency effects of M\&A of banks in Malaysia. For this purpose, Malaysian commercial banks were taken to analyze the technical efficiencies during the merger year, and study pre and post-merger period. Their results proved an overall increase in efficiency in the sample period, which is around $95.9 \%$. They also conclude that merger program was successful and the small size Malaysian banks. Although the financial sector especially banks took advantage and got benefits from mergers but some of the large banks faced certain inefficiencies of large scale from this indicate the quantitative findings of the research.

Ullah and Usman (2010) studied pre and post-merger performance in India and target the acquiring firms from diverse sectors and different industries but their major emphasis was on measurement of operating performance of the firms through financial ratios. They select the sample of all the mergers between public limited and trading firms during 1991-2003. The findings of this study did not show much impact in the post-merger operating performance of the firms in different industries in India.

\subsection{Theoretical Framework}

\subsubsection{Synergy Theory}

Faulkner-Bond, Waring, Forte, Crenshaw, Tindle, and Belknap, (2012) argue that the theory of synergistic merger holds that the managers of companies achieve efficiency gains by combining an efficient target with their business and then improving the performance of the target companies. Acquirers thus establish specific complementarities between their business and that of the target. This suggests that even though the target might already be performing well, it should perform even better when it is combined with its complementary counterpart, the acquiring firm.

Rajeswari (2010) also observes that the synergy theory suggests that, target firms or plants perform very well both before and after mergers. Gargitalic (2011) also contend that empirical research evaluating the synergistic potency of mergers and acquisition has generated mixed results.

\subsubsection{Concentration theory}

Proponents of the concentration theory argue that mergers and acquisitions promote the profitability while at the same time reducing fragility. They posit that through consolidation, weak and inefficient banks are eliminated thereby enhancing efficiency. Critics, however, argue that concentration of business firms can be counter-productive and may lead to inefficiency through reduced competition.

\subsection{Conceptual framework}

The model shows that the independents variables in the study are factors that lead the Mager and Acquisition conceptualized as providing variety of products and services, Cost efficiency, Fulfilling capital requirement, Assets acquisition and Economies of scale. One of target of a Bank Institution engaged in Merger and Acquisition is obtaining a larger customer bases through providing variety of products and services. The second is operating cost reduction through combining assets, activities and Human resources of two merged institutions..

\section{Independent Variables}

\section{Factors that lead the merger and acquisition in commercial banks}

- Providing variety of products \& service to clients

- Cost efficiency

- Fulfilling capital requirement

- Assets acquisition

- Economies of scale

\section{Dependent variables}

Factors that determine the performance of commercial banks

- Capital Adequacy Ratio

- The Return-on-Assets Ratio

- Return on Investment 


\section{Intervening variables}

\section{(Source: Researcher 2021) \\ Figure 1 Conceptual framework}

The dependent variable is factors that determine the performance of commercial banks which is measured in terms of trend of Capital Adequacy Ratio, the return On Assets Ratio, the Return On Investment Ratio and the Return on Equity Ratio. Those are key four Indicators of the Performance of a Commercial Bank which shows if the Bank Institution is performing or not after Merger and Acquisition.

The intervening variables show the external factors which might have an influence on the organizational performance. This includes the factors such as Management decision and company strategy. Management decisions basically depend on the leadership style of the company while company strategy depends on the long term goals and objectives of the company. These factors may also have an effect on organizational performance.

\section{RESEARCH METHODOLOGY}

\subsection{Research Design and Population}

The study used descriptive and correlative research design in a case study area in order to assess the variables in holistic manner. The study used this design to obtain the descriptions of a particular group of individuals and cross sectional survey that it enables the researcher to get data from a sample of the population at a particular time (Amin, 2005).

This was shown in the income statement and balance sheet for BPR Atlas Mara Bank, ECOBANK and I\&M Bank in the period from 2007 to 2018 depending to the period in which the Merger or Acquisition has been accomplished in each Bank under study.

The study targeted three banks in Rwanda namely the BPR Atlas Mara, I\&M Bank and Ecobank Rwanda. BPR Atlas Mara Bank has a total of 1020 employees countrywide, I\&M Bank has 430 while Ecobank Rwanda has 275 employees countrywide making total of 1724 employees being targeted. Due to the large number of employee's target, the researcher was not necessarily needed to collect data from all the employees. Only a smaller fraction was targeted especially those working in the in Kigali city was selected using both probability and non-probability sampling methods in order to avoid bias.

\subsection{Sample Design}

Due to the scarcity of resources such as limited time and efforts, the researcher had not involved all staff members therefore a sample was selected from Kigali headquarter office who consist of 385 staff from Atlas Mara Bank, 205 staff ant I\&M Bank and 160 at Ecobank working in the Kigali head quarter office.

Formula:

Where; $\mathrm{n}=\frac{N}{1+N(e)^{2}}$

$\mathrm{n}=$ is the minimum sample size

$\mathrm{N}=$ is the population from which the sample was drawn estimated at 750 employees from the bank

This publication is licensed under Creative Commons Attribution CC BY.

http://dx.doi.org/10.29322/IJSRP.11.05.2021.p11314

www.ijsrp.org 
$\mathrm{e}=$ is the margin of error estimated at $10 \%$. Substituting in the above formula, the sample size is determined as;

$\mathbf{n}=\frac{750}{1+750(0.1)^{2}}=\frac{750}{1+750(0.01)}=\frac{750}{1+7.5}=\frac{750}{8.5} \mathbf{n}=\mathbf{8 8}$

The researcher used probability sampling techniques to collect data from respondents in selected banks. In Probability sampling, the researcher used clustering to group the respondents in each banks. Employees were grouped into departments and in each department, simple random sampling was used to identify the participants to answer the questionnaire.

\subsection{Data Collection and Analysis}

During the course of the study, the researcher used both primary and secondary data sources. The data collected met the research objectives. Primary data was directly collected from the respondents while secondary data was obtained from bank institutions and documents of the selected commercial banks. For Secondary data, two years before and two years after the event of merger and acquisition was retrieved from audited financial statements, annual reports published by Central Bank of Rwanda (BNR) and the respective bank websites. Financial ratios: Return on Assets (ROA), Return on Equity (ROE), Return on Investment (ROI) and Capital Adequacy Ratio (CAR) were then obtained from the Financial statements and annual reports of commercial banks under study.

A self-administered questionnaire was addressed to the prospective respondents. The questionnaire consists of a title, an introduction, and questions on independent variable that is Factors that lead the Merger and Acquisition while questions on the dependent variable that is Factors that determine the performance of commercial banks was asked. Both open ended questions to obtain the in-depth feeling of respondents and close ended questions for easy administration were addressed to the respondents. The researcher asked permission from the university authority to continue with the study. After the researcher obtained the letter of introduction, the researcher was proceed with the approved research and distributed the questionnaire to the field, collected data from the field for analysis and interpretation. The researcher booked an appointment with the senior management of the selected banks and the data collection tools were administered within three working days to allow all the targeted respondents enough time to respond to the questionnaire tools.

The reliability of the instrument was computed using split half reliability test and spearman Brown Prophecy was applied to obtain the result. The researcher administered 20 questionnaires and the information was coded in SPSS for reliability test.

Table 1 Reliability Statistics

\begin{tabular}{lcccc}
\hline & $\mathrm{N}$ & $\%$ & Cronbach's Alpha & N of Items \\
\hline Valid & 20 & 98.8 & .982 & 42 \\
Excluded $^{\mathrm{a}}$ & 1 & 1.2 & & \\
Total & 20 & 100.0 & & \\
\hline
\end{tabular}

(Source: SPSS Output, 2021)

For instruments to be reliable, Cronbach Alpha has to be above 0.6 for it to be considered reliable. However, our study showed a value of 0.982 meaning that the instrument was $98.2 \%$ reliable.

Quantitative data were presented in tables, charts, and narratives. However, quantitative data were analyzed using Pearson correlation model and multiple regression models which took the form of:

$\mathrm{Y}=\beta 0+\beta 1 \mathrm{X} 1+\beta 2 \mathrm{X} 2+\beta 3 \mathrm{X} 3+\beta 4 \mathrm{X} 4+\beta 5 \mathrm{X} 5+\epsilon$

Where: $\mathrm{Y}=$ Probability of bank to either performing well or not 
$\mathrm{X} 1, \mathrm{X} 2, \mathrm{X} 3, \mathrm{X} 4$ and X5= Independent Variables

$\mathrm{X} 1=$ providing variety of products and services to its clients

$\mathrm{X} 2=$ Cost efficiency

$\mathrm{X} 3=$ Fulfilling capital requirement

$\mathrm{X} 4=$ Asset acquisition

$\mathrm{X} 5=$ Economy of scale

$\beta 0=$ Constant

$\beta 1, \beta 2, \beta 3 \beta 4 \beta 5=$ Regression coefficients or Change included in Y by each $\mathrm{X}$ value

$\epsilon=$ error term

Qualitative data were entered into a compilation sheet from which themes was identified. Each theme was transferred into a master sheet from which the analysis was done in relation to objectives of this study. Qualitative data were presented in form of narratives with verbatim reporting so that some strong feelings of respondents can be reported as they are.

\section{RESEARCH FINDINGS AND DISCUSSION}

\subsection{Introduction}

This part presents the analysis of the data collected from respondents using questionnaires. The researcher used SPSS, in to generate the summary which was used to analyze the data. The researcher entered the data in software while coding the responses provided by tested people for easy analysis. Tables are classified under different themes to enables easy presentation and interpretations of the data. Frequencies and percentages have been used as means of statistical analysis in the data presentations. Secondly, financial ratios: Return on Assets (ROA), Return on Equity (ROE), Return on Investment (ROI) and Capital Adequacy Ratio (CAR) obtained from financial statements and annual reports of commercial banks under study were analyzed to supplement the analysis from primary data from respondents.

\section{Response rate}

The researcher distributed 88 questionnaires to respondents, 85 of respondents managed to respond and return the questionnaires with fully required information which makes the response rate of $96 \%$. This means that the researcher made a strong follow up to get this very good result of response.

Table 2: Gender of the Respondents

\begin{tabular}{ccc}
\hline Gender & Frequency & Percent \\
\hline Male & 61 & 71.8 \\
Female & 24 & 28.2 \\
Total & 85 & 100.0 \\
\hline
\end{tabular}

Source: Primary Data (2021)

From the above table, the majority of the respondents were male (71.8\%) compared to (28.2\%) female. This indicates that the study was based on male opinions to a large extent and this was because of the large male population as members of I\&M Bank, ECOBANK and BPR Atlas Mara. This may imply that banking jobs attracts male gender as compared to female perhaps due to the nature that banks operates with a set targets and the pressure to achieve such targets might be intense.

Table 3 Age group of the Respondents 


\begin{tabular}{lcc}
\hline Age group & Frequency & Percent \\
\hline Under 20 years & 5 & 5.9 \\
$21-30$ years & 28 & 32.9 \\
$31-40$ years & 43 & 50.6 \\
41 years and above & 9 & 10.6 \\
Total & 85 & 100.0 \\
\hline
\end{tabular}

\section{Source: Primary Data (2021)}

Majority of the respondents were in the age groups 31- 40 and 21- 30 representing 50.6\% and $32.9 \%$ respectively while the least number of respondents were under 20 years $5.6 \%$ and $10.6 \%$ above 41 . This means that the most targeted population were middle aged employees above 30 years who have garnered wealth of experience during their work careers and are still strong and economically active.

\section{Table 4. Banking Institutions}

\begin{tabular}{ccc}
\hline Bank institutions & Frequency & Percent \\
\hline Atlas Mara & 50 & 58.8 \\
Ecobank & 15 & 17.6 \\
I\&M Bank & 20 & 23.5 \\
Total & 85 & 100.0 \\
\hline
\end{tabular}

\section{Source: Primary Data (2021)}

The study established that $58.8 \%$ of the respondents were employees from Atlas Mara bank, 23.5\% were from I \&M Bank and 17.6\% were employees from Ecobank. Majority of the participants in the study were from Atlas Mara bank because it is the most recent bank to undergo M\&A and also has the largest number of employees as compared to the rest of the banks in Rwanda.

\section{Table 5. Highest Education Level of Respondents}

\begin{tabular}{ccc}
\hline Education Level & Frequency & Percent \\
\hline Intermediate (High school) & 14 & 16.5 \\
Bachelors & 62 & 72.9 \\
Masters & 9 & 10.6 \\
Total & 85 & 100.0 \\
\hline
\end{tabular}

\section{Source: Primary Data (2021)}

From the above table, $10.6 \%$ have Master degree level, $72.9 \%$ have Bachelor's degree, $16.5 \%$ attained Intermediate educational level. This showed that the majority of the respondents were well educated and therefore were able to secure a job in the banking sector. It also means that they knew what they were answering as almost $80 \%$ had a minimum of a degree. Majority of those who had Master degree were mainly at top management level perhaps due to gradual promotion based on their credentials. Majority of the bachelor degree holders were spread across the various departments in various positions mainly at the middle management level and others at lower management level based on their level of experience working in the banking sector.

\subsection{Factors which lead to merger and acquisition in Commercial Banks}


The study sough to assess some of the factors which may transpire and lead the banks to either merge of acquired in the market. Various reasons were suggested and the respondents were allowed to give their opinions. The following section presents the summary of the responses which are presented using mean distribution and the standard deviation as indicated below;

\section{Table 6. Factors that lead the merger and acquisitions in Commercial Banks}

\begin{tabular}{lcc}
\hline Factors of M\&A in banks & Mean & Std. Deviation \\
\hline Providing variety of products and services to clients & 4.99 & .108 \\
Cost efficiency & 4.01 & .108 \\
Fulfilling capital requirement & 4.04 & .241 \\
Assets acquisition & 4.21 & .439 \\
Economies of scale & 4.86 & 5.523 \\
Valid N (listwise) & & \\
\hline
\end{tabular}

\section{Source: Primary Data (2021)}

The study indicates in the above table that some of the determinants factors for M\&A in financial institutions include; providing variety of products and services to clients $(M e a n=4.99)$, cost efficiency (Mean=4.01), fulfilling capital requirement $($ Mean= 4.01), assets acquisition (Mean=4.21) and economies of scale (Mean=4.86). These variables are elaborated better in subsequent tables.

Table 7. Statistics showing reasons for M\&A to increase income

\begin{tabular}{lcc}
\hline How M\&A leads to increase income & Mean & Std. Deviation \\
\hline $\begin{array}{l}\text { Merger and acquisition may increase the net interest income (difference in } \\
\text { revenue resulting from bank's assets and expenses associated with paying out its }\end{array}$ & 4.20 & .483 \\
$\begin{array}{l}\text { liabilities) of banks } \\
\text { Merger and acquisition may increase the noninterest income (income resulting } \\
\text { from deposit fees, service charges, deposit slip fees etc.) of banks }\end{array}$ & 4.15 & .394 \\
$\begin{array}{l}\text { Economies of scale (providing more services at proportionate saving in costs) may } \\
\text { not be obtained through merger and acquisition }\end{array}$ & 1.99 & .244 \\
$\begin{array}{l}\text { Multiple sources of income or economies of scope (providing two or more distinct } \\
\text { services with less cost had they been done individually) can be introduced with the } \\
\text { help of merger and acquisition }\end{array}$ & 4.98 & .152 \\
$\begin{array}{l}\text { Merger and acquisition helps to increase the customer activity (such as increase in } \\
\text { opening bank accounts, banking transaction, use of safe deposits etc). }\end{array}$ & 3.99 \\
Valid N (listwise) & & .523 \\
\hline
\end{tabular}

\section{Source: Primary Date (2021)}

From the table 4.4 shows response indicating that majority of the respondents agreed either strongly or normally that merger and acquisition in the banks is being done for the sole interest of increasing income as one of the reasone. The parameteres used to measure the level of agreement is indicated bellow.

Table 8 Statistics showing that the reason for M\&A may increasing sales of services

\begin{tabular}{lcc}
\hline How M\&A leads to increase in sales of services & Mean & Std. Deviation \\
\hline $\begin{array}{l}\text { Opening of banks' branches would not be easier because of merger and } \\
\text { acquisition. }\end{array}$ & 4.09 & .366 \\
$\begin{array}{l}\text { In order to provide new services to customers, merger and acquisition is one of } \\
\text { the easiest option }\end{array}$ & 4.72 & .453
\end{tabular}


Merger and acquisition is not an effective tool for executing the Expansion strategy (attempting to achieve high growth with comparison to previous achievement) of the banks

Merger and acquisition makes it possible for the banks reach new customers easily together than they could have done alone.

Merger and acquisition is one of the effective tool to understand and apply the methods of providing more services to more customers

Valid N (listwise)

\section{Source: Primary Data (2021)}

On the issue that M\&A may increase sales of service, the study developed 5 statements which were used to describe ways in which this can be achieved. The study reveals that majority of the respondents strongly agreed that M\&A leads to increase in bank sales services due to various reasons. The respondents ranked them from the most supported option to the least supported statement below. The first on was that majority of the respondents strongly agreed that merger and acquisition is one of the effective tool to understand and apply the methods of providing more services to more customers, the study was rated with a mean of $(4.51 \leq$ mean score $4.81 \leq$ 5.00) meaning that majority of the respondents strongly agreed with this variable.

The second rating was that majority of the respondents also strongly agreed that M\&A in the bank may lead into increase in sales. In order to provide new services to customers, merger and acquisition is one of the easiest option $(4.51 \leq$ mean score $=4.72 \leq 5.00)$

Thirdly, on the aspect that merger and acquisition makes it possible for the banks reach new customers easily together than they could have done alone majority of the respondnts strongly agreed with this variable as indicated by a mean of $(4.51 \leq$ mean score $=4.69 \leq$ 5.00).

The forth one was that majority of the respondents supported that opening of banks' branches would not be easier because of merger and acquisition as indicated by a $(3.51 \leq$ mean score $=4.09 \leq 4.50)$ meaning that majority of them agreed normally with this statement. Finally, on the statement which stated that merger and acquisition is not an effective tool for executing the Expansion strategy of the banks, the responses disagreed with this statement as indicated by a mean $(1.51 \leq$ mean score $=2.02 \leq 2.50)$.

Table 9 Statistics showing that the reason for M\&A may affect cost efficiency

\begin{tabular}{lcc}
\hline How M\&A may affect cost efficiency & Mean & Std. Deviation \\
\hline Merger and acquisition does not help to minimize the duplication of efforts & 2.92 & .317 \\
Merger and acquisition is done in order to reduce the overall weakness of & 4.00 & .345 \\
the merged/acquired banks. & \multirow{2}{*}{.9300} \\
Merger and acquisition does not make it possible to eliminate branch & .237 \\
overlapping. & 4.06 \\
In order to reduce unnecessary managerial as well as operational positions, \\
merger and acquisition among banks can be done \\
In order to produce more without increasing the individual capacity of \\
banks, merger and acquisition is performed. \\
Valid N (listwise)
\end{tabular}

\section{Source: Primary Data (2021)}

While seeking to assess whether M\&A may affect the cost efficiency of the bank, also various statements were presented to the respondents in order to give their rating and below are the summary of the statistics; 
On the issue stating that "in order to reduce unnecessary managerial as well as operational positions, merger and acquisition among banks can be done", the study rated this variables with the highest mean of $(3.51 \leq$ mean score $=4.06 \leq 4.50)$ meaning majority of the respondents strongly agreed.

Secondly, merger and acquisition is done in order to reduce the overall weakness of the merged/acquired banks as indicated by a mean rating of $(3.51 \leq$ mean score $=4.00 \leq 4.50)$ meaning that majority of the respondents agreed that by so doing, will reduce cost and facilitate efficiency of the banking institution.

Thirdly, the study indicates that in order to produce more without increasing the individual capacity of banks, merger and acquisition is performed. This was evidently shown by responses rated with a mean of $(3.51 \leq$ mean score $=4.00 \leq 4.50)$ meaning that majority of the respondents also agreed with the same opinion floated to them.

Fourthly, on the statement which stated that "merger and acquisition does not make it possible to eliminate branch overlapping", the study rated this variable with a lowest mean on $(2.51 \leq$ mean score $=2.93 \leq 3.50)$ meaning the majority of the respondents were undecided on this statement.

Similarly, regarding the statement which states that "Merger and acquisition does not help to minimize the duplication of efforts", the study rated this statement with a mean of $(2.51 \leq$ mean score $=2.92 \leq 3.50)$ also meaning that majority of the respondents were undecided on this statement as well. In such scenario, there are many of them who believe that M\&A help to minimize the duplication of efforts in financial institutions.

\section{Table 10 Statistics showing that M\&A is done purposely for financial diversification}

\begin{tabular}{lcc}
\hline How M\&A affects financial diversification & Mean & Std. Deviation \\
\hline $\begin{array}{l}\text { In order to provide different types of products/services to the customers, } \\
\text { merger and acquisition is done. }\end{array}$ & 4.26 & .580 \\
$\begin{array}{l}\text { In order to achieve success in key area of operations, merger is done with } \\
\text { banks having deeper market penetration i.e. banks whose services have high } \\
\text { customer usage in market. }\end{array}$ & 3.91 & .332 \\
$\begin{array}{l}\text { Merger and acquisition is not performed for the sake of managing the financial } \\
\text { complexities (example: managing the non-performance of certain services). }\end{array}$ & 2.94 & .389 \\
$\begin{array}{l}\text { Merger and acquisition does not have any role in creating portfolio of banks' } \\
\text { products/services. }\end{array}$ & 2.86 & .350 \\
$\begin{array}{l}\text { In order to minimize the risk in the market, merger and acquisition is } \\
\text { performed by banks as a part of related diversification (activities that are }\end{array}$ & 3.98 \\
$\begin{array}{l}\text { similar to the one currently offered). } \\
\text { Valid N (listwise) }\end{array}$ & .408 \\
\hline
\end{tabular}

Source: Primary Data (2020)

To start with, the study indicates that financial diversification can be undertaken in order to provide different types of products/services to the customers. This can be facilitated by merger and acquisition and majority of the respondents agreed with this statement as indicated by a mean rating $(3.51 \leq$ mean score $=4.26 \leq 4.50)$.

Secondly, in order to minimize the risk in the market, merger and acquisition is performed by banks as a part of related diversification (activities that are similar to the one currently offered). This statement was also supported by majority of the respondents who participated in this exercise as indicated by a mean rating of $(3.51 \leq$ mean score $=3.98 \leq 4.50)$.

Thirdly, in order to achieve success in key area of operations, merger is done with banks having deeper market penetration i.e. banks whose services have high customer usage in market, majority of the respondents rated this statement with a mean value of $(3.51 \leq$ mean score $=3.91 \leq 4.50$ ), meaning that majority of the respondents also supported this statement to be true. 
On the other hand the statement citing that merger and acquisition is not performed for the sake of managing the financial complexities (example: managing the non-performance of certain services), majority of the respondent regarded this statement to be false while others decided to be neutral as indicated by a mean of $(2.51 \leq$ mean score $2.94 \leq 3.50)$. Again on the issue that merger and acquisition does not have any role in creating portfolio of banks' products/services, majority of the respondents remained neutral as indicated by a mean rating of $(2.51 \leq$ mean score $2.86 \leq 3.50)$.

Diversification refers to a strategy of buying firms outside of a company's current primary lines of business. De Pampihilla (2010) has stated that a company that merges to diversify may acquire another company in a seemingly unrelated industry in order to reduce the impact of a particular industry's performance on its profitability. Companies seeking to sharpen focus often merge with companies that have deeper market penetration in a key area of operations (Renaud, 2016). The above table indicates that in order to obtain power to exclude rivals, banks go through merger and acquisition. This was supported by majority of respondents who strongly agreed with this variable as indicated by a mean rating of $(4.51 \leq$ mean score $=4.79 \leq 5.00)$.

This was followed by those who stated that merger and acquisition helps the banks to achieve unique selling proposition (factor that distinguish product from that of competitors) by combining successful services from them before merger and acquisition as indicated by a mean ration of $(3.51 \leq$ mean score $=4.02 \leq 4.50)$ meaning that majority of them agreed normally with this variable.

Regarding the statement which stated that merger and acquisition does not have any role to capture market share, majority of the respondents were neutral in answering this question as indicated by a mean of $(2.51 \leq$ mean score $=3.00 \leq 3.50)$. when it comes to the statement stating that merger and acquisition are not an effective tool for eliminating competition, majority of the respondents disagreed with this statement as indicated by a mean of $(1.51 \leq$ mean score $=2.06 \leq 2.50)$. This means that this statement is false and they rather support the opposite of it. Finally, on the statement citing that merger and acquisition does not make it easier for companies to obtain better position by increasing its size, majority of the respondents disagreed as indicated by a mean of $(1.51 \leq$ mean score $=1.95 \leq 2.50$ )

Table 11 showing that M\&A help to obtain stronger position in market

\begin{tabular}{lcc}
\hline How M\&A strengthens market positioning & Mean & Std. Deviation \\
\hline $\begin{array}{l}\text { In order to obtain power to exclude rivals, banks go through merger and } \\
\text { acquisition. }\end{array}$ & 4.79 & .692 \\
Merger and acquisition does not have any role to capture market share. & 3.00 & .154 \\
Merger and acquisition are not an effective tool for eliminating competition. & 2.06 & .237 \\
Merger and acquisition does not make it easier for companies to obtain better & 1.95 & .263 \\
position by increasing its size. & & .217 \\
Merger and acquisition helps the banks to achieve unique selling proposition & \\
(factor that distinguish product from that of competitors) by combining & 4.02 \\
successful services from them before merger and acquisition & \\
Valid N (listwise) & \\
\hline
\end{tabular}

\section{Source: Primary Data (2021)}

As suggested by market power theory, firms merge to improve their monopoly power to set product prices at levels not sustainable in a more competitive market. Many merger and acquisition deals allow the acquirer to eliminate competition and gain larger market share in its product's market (Reaund, 2016).

\section{Table 4.1: Statistics showing M\&A helps to build a better branding}




\begin{tabular}{|c|c|c|}
\hline How M\&A affects better branding & Mean & Std. Deviation \\
\hline $\begin{array}{l}\text { Merger and acquisition is done to increase the positioning of banks in the mind } \\
\text { of the customers. }\end{array}$ & 4.55 & .838 \\
\hline $\begin{array}{l}\text { Merger and acquisition makes it possible to gain image of banks with less } \\
\text { activities to be performed than had they done individually. }\end{array}$ & 3.92 & .277 \\
\hline $\begin{array}{l}\text { Merger and acquisition cannot help to obtain branding of banks within short } \\
\text { span of time }\end{array}$ & 2.22 & .419 \\
\hline $\begin{array}{l}\text { Merger and acquisition helps to create the brand of banks with involvement of } \\
\text { less cost than had it been done individually. }\end{array}$ & 4.00 & .767 \\
\hline $\begin{array}{l}\text { Merger and acquisition does not make it easy for the advertisement of banks to } \\
\text { reach to the large number of consumers than had it been done alone. } \\
\text { Valid N (listwise) }\end{array}$ & 3.22 & .419 \\
\hline
\end{tabular}

\section{Source: Primary Data (2021)}

When it comes to building the brand of the bank, the study sought know whether merger and acquisition is done to increase the positioning of banks in the mind of the customers. According to the statistics, majority of the respondents strongly agreed with this variable as indicated by a mean ration of $(4.51 \leq$ mean score $=4.55 \leq 5.00)$.

When it comes to the statement stating that merger and acquisition makes it possible to gain image of banks with less activities to be performed than had they done individually, majority of the respondents strongly agreed with this variable as indicated by a mean rating of $(3.51 \leq$ mean score $=3.92 \leq 4.50)$

It was also noted that merger and acquisition helps to create the brand of banks with involvement of less cost than had it been done individually. This was evidently shown by majority of the respondents who agreed with this statement as indicated in $(3.51 \leq$ mean score $=4.00 \leq 4.50)$.

Regarding the statement which states that merger and acquisition does not make it easy for the advertisement of banks to reach to the large number of consumers than had it been done alone, majority of the respondents were neutral on this statement as indicated by a mean of $(2.51 \leq$ mean score $=3.32 \leq 3.50)$. This statement actually is not true because M\&A enables advertisement of the bank to reach to a large number of customers bearing in mind that each bank had its own clients prior to the merger or acquisition.

The study also indicated that majority of the respondents disagree that merger and acquisition cannot help to obtain branding of banks within short span of time. This is evidently shown by a mean rating of their response indicated as $(1.51 \leq$ mean score $=2.22 \leq 2.50)$.

\section{3 Factors that determine the financial performance of commercial banks}

The study also wanted to assess some of the key parameters used in financial institutions to measure financial performance of the bank. The following section provides insight on some of the identified tools used to measure financial performance.

Table 13. Factors that determine the financial performance of commercial banks

\begin{tabular}{lcc}
\hline Factors used to measure financial performance & Mean & Std. Deviation \\
\hline Capital adequacy ratio & 4.05 & .213 \\
The return on assets ratio & 4.05 & .213
\end{tabular}


Return on equity

Liquidity

Valid N (listwise)

\section{Source: Primary Data (2021)}

In average, majority of the respondents who were asked to rate whether the proposed tools were used to assess financial performance agreed as indicated below; capital adequacy ratio agreed normally with a mean of (Mean=4.05), the return on assets ratio was rated with a mean of (Mean=4.05), Return on investment was rated with a mean of $(\mathrm{Mean}=4.02)$, return on equity was used with a mean of $(M e a n=5.00)$ and finally the liquidity was rated with a $(M e a n=4.34)$. However, the most preferred tool used to assess the financial performance of the bank is the ROE as indicated by all respondents who seems to overwhelmingly support this assertion.

The following section provides the statistics of the financial performance of the three banks which were sampled and had undergone M\&A although during different periods. However, the researcher obtains some statistics based on 2 years before M\&A and 2 years after undergoing M\&A.

\section{Figure 4.1: Assessment of CAR before and after M\&A in banks}

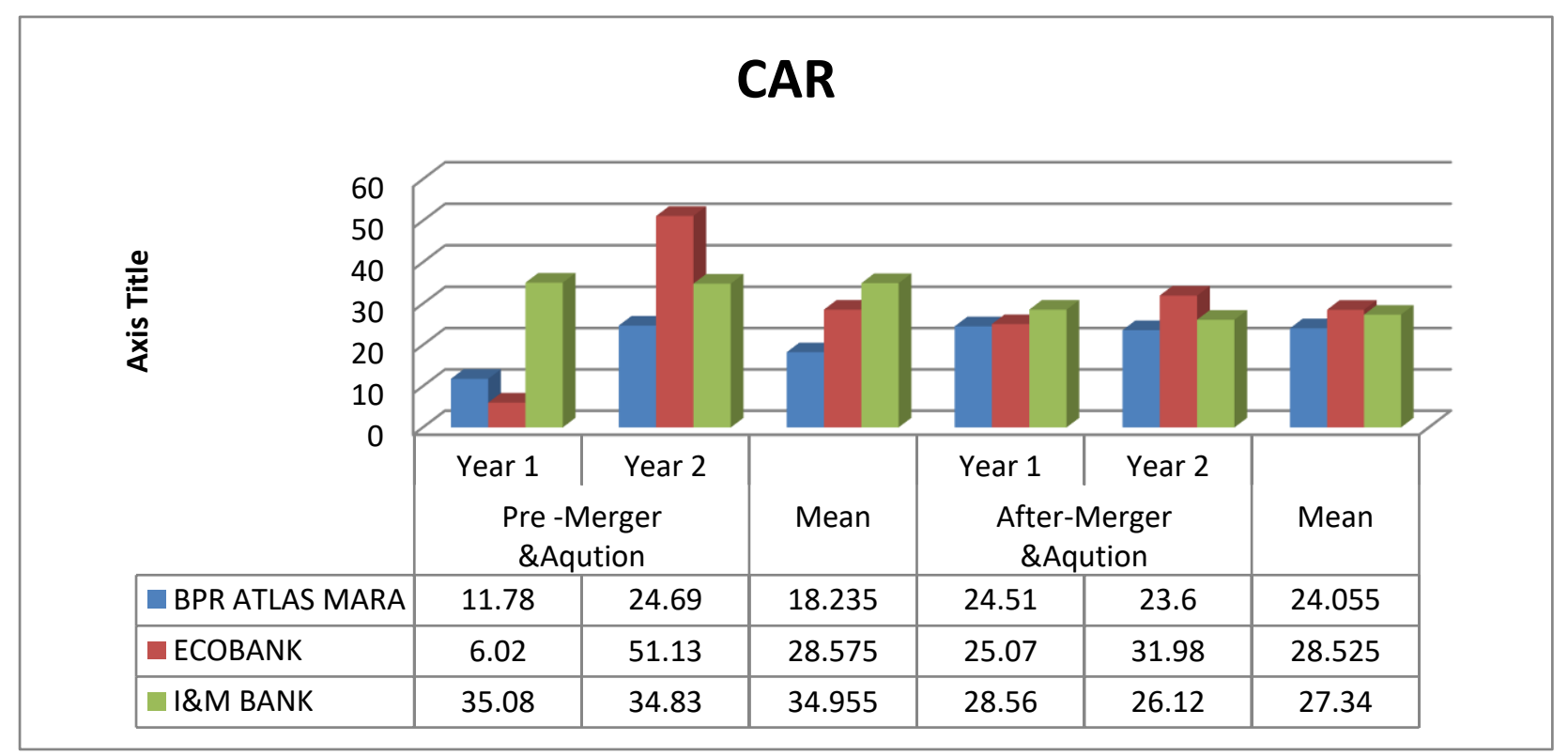

\section{Source: Secondary Data (2020)}

The study indicates that within the first 2 years before M\&A the CAR at BPR Atlas Mara bank was ranging on the average of $18.2 \%$ but immediately after the M\&A the average started to increase to about $24.5 \%$. In Ecobank, the average was estimated at $28.5 \%$ but 2 years after M\&A it still maintained the same amount of $28.5 \%$ but the discrepancy was significantly reduces owing that at one point there was a gap of about $45 \%$ during the first 2 years before M\&A.

In I\&M Bank, the study indicates that in average CAR average of the two years before M\&A was $35 \%$ but then followed by a slight decrease to about $27.3 \%$ two years later after M\&A. This might have been caused by capitalization and the amount injected capital in the business after the M\&A.

\section{Figure 4.2: Assessment of ROE before and after M\&A in banks}




\section{ROA}

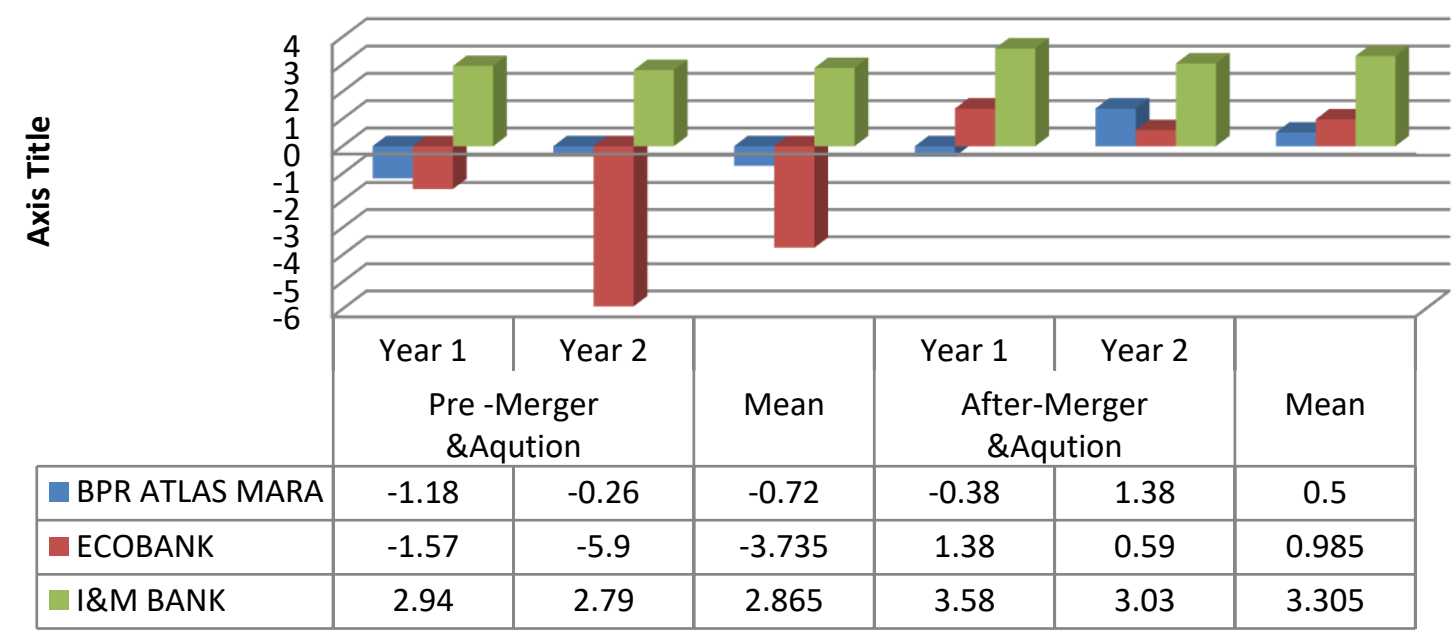

Source:

\section{Secondary Data (2020)}

Looking at the financial trend on ROA for the three banks before M\&A and after M\&A, the study clearly indicates that there was a positive improvement as well. Two yers before before M\&A, the ROI in BPR Atlas Mara was calculated at -1.18 in at the first year and -0.26 at the second year. After the M\&A, the first year still recorder -0.38 and the subsequent year increased to 1.38 . It is also observed that in Ecobank, there was a similar trend where by 2 years before M\&A the ROA were showed a negative figures but immediately after the M\&A the figures started to show a positive growt

Figure 4.3: Assessment of ROI before and after M\&A in banks

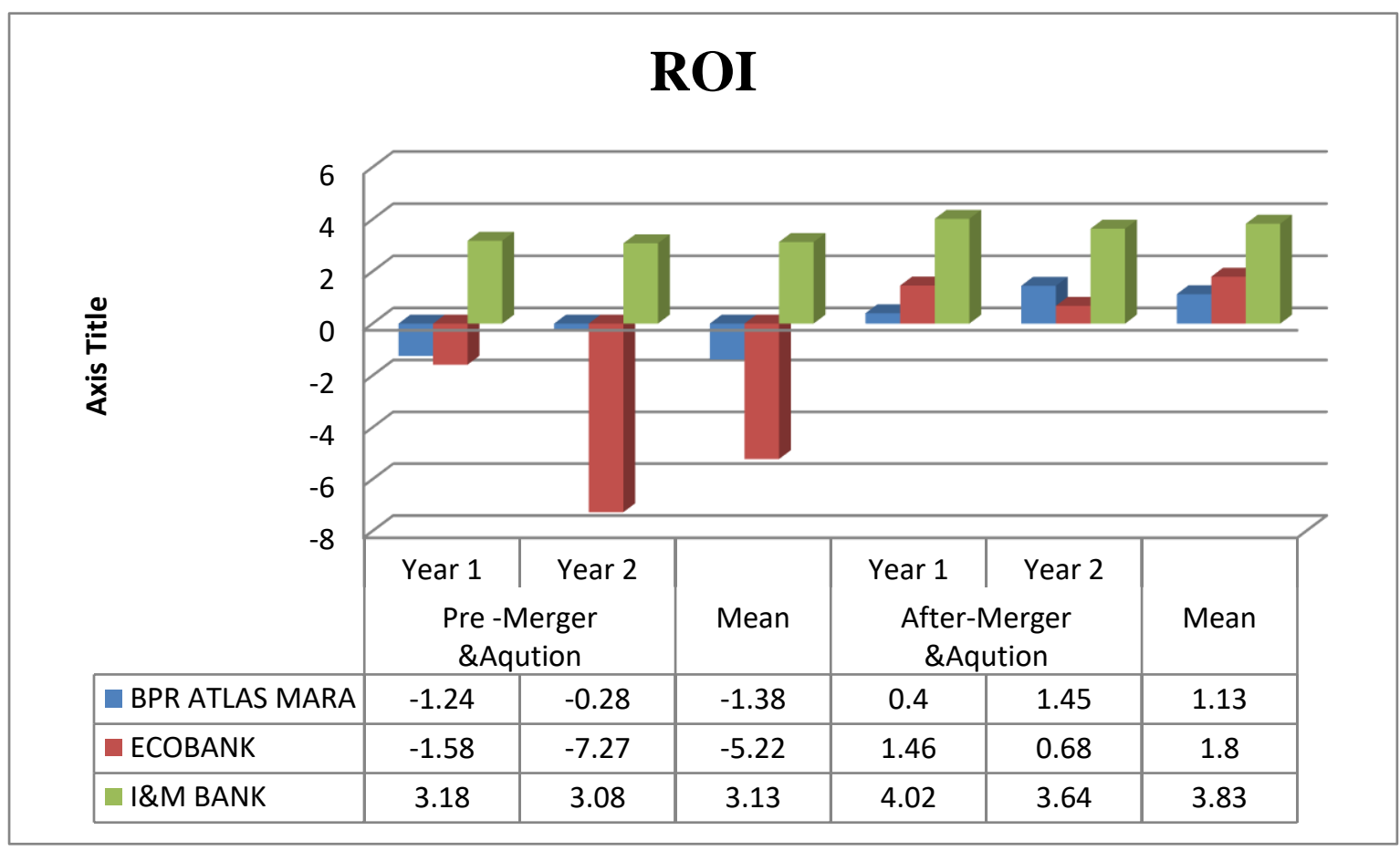


The study also used Return on Equity to assess the performance of commercial banks befor and after M\&A and it was observed that M\&A enabled the commercial banks to icrease their ROI as indicared in the figure 4.4. the average mean on the ROI for the last two years befor marger was -1.38 in BPR Atlas Mara and immediaely increased to a mean of 1.13 after the first two years of M\&A. Similarly, in Ecobank, the performance increased significantly from an average of -5.22 for the last two years before marger to 1.8 for the first two years after M\&A. in I\&M Bank, the ROI increased from a mean of 3.13 to a mean of 3.83 after the marger. This implies that M\&A enabled the commercial banks to increase their ROI. This is a good indicator for the investor that if he/she invests in the business, he is asssured that the business will return the amount invested in the business. 


\subsubsection{Relationship merger and acquisition factors on the performance of banks in Rwanda}

Table 4.2: Regression analysis for Capital adequacy ratio on independent variables

\begin{tabular}{|c|c|c|c|c|c|}
\hline \multirow[t]{2}{*}{ Model } & \multicolumn{2}{|c|}{ Unstandardized Coefficients } & $\begin{array}{l}\text { Standardized } \\
\text { Coefficients }\end{array}$ & \multirow[t]{2}{*}{$\mathrm{T}$} & \multirow[t]{2}{*}{$\begin{array}{l}\text { Sig.(P- } \\
\text { value) }\end{array}$} \\
\hline & B & Std. Error & Beta & & \\
\hline (Constant) & -.268 & .140 & & -1.910 & .060 \\
\hline $\begin{array}{l}\text { Providing variety of } \\
\text { products and services to } \\
\text { clients }\end{array}$ & .126 & .050 & .116 & 2.527 & .013 \\
\hline Cost efficiency & .126 & .045 & .121 & 2.798 & .006 \\
\hline $\begin{array}{l}\text { Fulfilling capital } \\
\text { requirement }\end{array}$ & .778 & .048 & .785 & 2.156 & .000 \\
\hline Asset aquisition & .248 & .034 & .125 & 2.238 & .000 \\
\hline Economies of scale & .192 & .044 & .785 & 2.156 & .000 \\
\hline
\end{tabular}

a. Dependent Variable: Capital adequacy ratio

\section{Source: Primary Date (2020)}

Using linear regression analysis from SPSS data bases, a number of business merger and acquisition in regard to Capital Adequacy Ratio were regressed to find out how they impacted on financial performance. The coefficient table shows the test of each predictor (Providing variety of products and services to clients with a p-value of .013 and indicates a strong relationship between the variables; cost efficiency with a p-value of .006 indicating a significant relationship wih the variables and fulfilling capital requirement with a pvalue of .000); asset acquisition with p-value of .000 and economies of scale with p-value of .000. The p-value is less that 0.05 which meaning that there is a significant relationship on financial performance of the bank. The equation of the line is indicated as $(\mathrm{Y}=\beta 0+$ $\beta 1 \mathrm{X} 1+\beta 2 \mathrm{X} 2+\beta 3 \mathrm{X} 3+\beta 4 \mathrm{X} 4+\beta 5 \mathrm{X} 5+\mathrm{C}$ ). If we substitute the formula then we will come up with the following equation: $\mathrm{CAR}=$ $0.126+0.126+.778-0.268$. This implies that Capital adequacy (= is a product of) .126 (provision of variety products and services to clients $)+.126$ Cost efficiency +.778 (Fulfilling capital requirement) +.248 (asset acquisition) +0.192 (economies of scale) -.268 (Constant). The model summary indicated that the $\mathrm{R}^{2}$ of the equation was 0.42 which means that in linear regression the model is $42 \%$ able to show how much it explain in the five dependent variables. It indicates the amount of variance in that are accounted for or explained by dependent variable.

Table 4.3: Regression analysis for the return on assets ratio on the independent variables

\begin{tabular}{|c|c|c|c|c|c|c|}
\hline \multirow{2}{*}{\multicolumn{2}{|c|}{ Model }} & \multicolumn{2}{|c|}{ Unstandardized Coefficients } & $\begin{array}{l}\text { Standardized } \\
\text { Coefficients }\end{array}$ & \multirow[t]{2}{*}{$\mathrm{T}$} & \multirow[t]{2}{*}{ Sig. } \\
\hline & & B & Std. Error & Beta & & \\
\hline & (Constant) & 1.004 & .275 & & 3.647 & .000 \\
\hline & $\begin{array}{l}\text { Providing variety of } \\
\text { products and services to } \\
\text { clients }\end{array}$ & .439 & .098 & .387 & 4.469 & .000 \\
\hline & Cost efficiency & .048 & .089 & .044 & .541 & .590 \\
\hline
\end{tabular}




\begin{tabular}{lccccc} 
Fulfilling capital & 1.107 & .094 & 1.076 & 11.710 & .000 \\
requirement & & & & & \\
Asset aquisition & .236 & .055 & .231 & 2.799 & .012 \\
Economies of scale & .799 & .068 & .785 & 6.136 & .030 \\
\hline
\end{tabular}

a. Dependent Variable: The return on assets ratio

\section{Source: Primary Date(2020)}

The coefficient table shows the test of each predictor (Providing variety of products and services to clients with a p-value of .000 < 0.05 meaning that there is strong relationship with financial performance of the bank; cost efficiency with a p-value of $.596>0.05$ meaning that there is no significant relationship on financial performance and fulfilling capital requirement with a p-value of .000, asset acquisition with p-value of .012 and economies of scale with p-value of $.030<0.05$ meaning that there is strong relationship with financial performance of the bank). The equation of the line is indicated as $(\mathrm{Y}=\beta 0+\beta 1 \mathrm{X} 1+\beta 2 \mathrm{X} 2+\beta 3 \mathrm{X} 3+\beta 4 \mathrm{X} 4+\beta 5 \mathrm{X} 5+\epsilon)$. If we substitute the formula then we will come up with the following equation:

$\mathrm{ROA}=0.439+0.048+1.107+.236+.799+1.004$. This implies that Return on Assets (= is a product of) 0.439 (Providing variety of products and services to clients) +0.048 Cost efficiency +1.107 (Fulfilling capital requirement) +.236 (asset acquisition) +.799 (economies of scale) 1.004 (Constant). The model summary indicated that the $\mathrm{R}^{2}$ of the equation was 0.48 which means that in linear regression the model is $48 \%$ able to show how much it explain in the five dependent variables

Table 4.4: Regression analysis for Return on investment on independent variables

\begin{tabular}{|c|c|c|c|c|c|}
\hline \multirow[t]{2}{*}{ Model } & \multicolumn{2}{|c|}{ Unstandardized Coefficients } & $\begin{array}{l}\text { Standardized } \\
\text { Coefficients }\end{array}$ & \multirow[t]{2}{*}{$\mathrm{T}$} & \multirow[t]{2}{*}{ Sig. } \\
\hline & B & Std. Error & Beta & & \\
\hline (Constant) & .878 & .329 & & 2.670 & .009 \\
\hline $\begin{array}{l}\text { Providing variety of } \\
\text { products and services to } \\
\text { clients }\end{array}$ & .253 & .117 & .230 & 2.159 & .034 \\
\hline Cost efficiency & .184 & .106 & .175 & 1.742 & .005 \\
\hline $\begin{array}{l}\text { Fulfilling capital } \\
\text { requirement }\end{array}$ & .805 & .113 & .808 & 7.137 & .000 \\
\hline Asset aquisition & .226 & .085 & .132 & 2.708 & .003 \\
\hline Economies of scale & .778 & .048 & .787 & 7.156 & .020 \\
\hline
\end{tabular}

a. Dependent Variable: Return on investment

\section{Source: Primary Date(2020)}

The coefficient table shows the test of each predictor (Providing variety of products and services to clients with a p-value of .034 $<0.05$ showing a strogn relationship on financial performance of the bank; cost efficiency with a p-value of $.085>0.05$ which has no relationship on financial perfornace of the bank and fulfilling capital requirement with a p-value of .000, asset acquisition with pvalue of .003 and economies of scale with p-value of $.020<0.05$ showing a strong relationship on financial performance). The equation of the line is indicated as following equation: $\mathrm{ROI}=.253+.184+.805+.226+.778+.878$. This implies that Return on Investment ( $=$ is a product of) 0.253 (Providing variety of products and services to clients) +0.184 Cost efficiency +0.805 (Fulfilling capital requirement) +0.226 (asset acquisition) +0.778 (economies of scale) +0.878 (Constant). The model summary indicated that 
the $\mathrm{R}^{2}$ of the equation was 0.53 which means that in linear regression the model is $53 \%$ able to show how much it explain in the five dependent variables

\section{CONCLUSION AND RECOMMANDATIONS}

\subsection{Conclusion}

The main purpose of conducting this study was aimed at establishing the link between merger and acquisition of the bank and its effects on financial performance. Their significant contribution in the merger and acquisitions decision was carried out in the context of Rwandan banking scenario.

The study indicates five main factors that determine M\&A in financial institutions include; providing variety of products and services to clients, cost efficiency, fulfilling capital requirement, asset acquisition and economies of scale. This will lead to the increase in financial performance of the bank in terms of the capital adequacy ratio, return on assets, return on investment, return on equity and the liquidity of the bank.

Financial performance ( $=$ is a product of) 0.283 (Providing variety of products and services to clients) +0.262 Cost efficiency +0.791 (Fulfilling capital requirement) +0.309 (asset acquisition) +0.524 (economies of scale) +0.598 (Constant). This implies that merger and have positive impact on financial performance of the bank. The purpose of M\&A is to provide variety of products and services to the customets, operate cost efficiently, fulfil capital requirement, aquire more assets and maximize the ecnomies of scale. This leads to increase in Return on Assets, Capital Adequacy Ratio, Return on Equity and return on Investment in the banking sector.

\subsection{Recommendations}

The researcher has observed the following recommendations in order to boast the bank performance. Banks should continue to embrace M\&A in order to improve the financial performance of the bank. This should be recommended to be undertaken by small banks in order to increase their competitiveness in the market. Besides, the post-M\&A scenario enables an organization to secure for itself a better and competitive position within the industry and a greater level of competence associated with consolidation enable such organizations to materialize customer expectation in a more effective manner, thus achieving the level of both economies of scales and scopes.The banks should increase on their capital structure in order to operate effectively and efficiently, and strive to efficiently management of assets at their disposal at a minimum cost. This will increase bank's profitability and encourage the shareholder to invest more in the bank. The banks should use up to date technology in order to improve efficiency and effectively. Even it has been proven in this study, that Merger and Acquisition has a positive effect on the performance of the Bank, to be effective, this should be accompanied with the up to date and strong technology.

\section{REFERENCES}

Afza, T., \& Yusuf, M. U. (2012). The Impact of Mergers on Efficiency of Banks in Pakistan. Elixir International Journal: 9158-9163.

Akben-Selcuk, A.A. (2011). The Impact of Mergers and acquisitions on Acquirer performance: Evidence from Turkey. Business and Economics Journal, 11, 22-29

Alam, A., Khan, S. \& Zafar, F. (2014). Strategic Management: Managing Mergers \& Acquisitions. International Journal of BRIC Business Research, 3, 1-10

André, P., Ben-Amar, W., \& Saadi, S. (2014). Family firms and high technology mergers \& acquisitions. Journal of Management and Governance, 18(1),129-158. 
Andreou, P.C., Louca, C., \& Panayides, P.M. (2012). Valuation Effects of Mergers and Acquisitions in Freight Transportation. Transportation Research, 1221-1234.

Arshad, A. (2012). Post-merger Performance Analysis of Standard Chartered Bank Pakistan. Interdisciplinary Journal of Contemporary Research in Business, 164-173.

Asimakopoulos, I., \& Athanasoglou, P.P. (2013). Revisiting the Merger and Acquisition Performance of European Banks. International Review of Financial Analysis, 237-249.

Bashir, A., Sajid, M.R., \& Sheikh, S.F. (2011). The Impact of Mergers and Acquisitions on Shareholders Wealth: Evidence from Pakistan. Middle-East Journal of Scientific Research, 261-264.

Berger, A., Bouwman, C., (2010). How does capital affect bank performance during financial crises? Wharton Financial Working paper, 11-22.

Bernard, S.B. (2015). Shareholder Wealth Maximization and Its Implementation Under Corporate Law, 66 Fla. L. Rev. 389.

Duppati, G., Abidin, S., Hu, J. (2015). Do mergers and acquisitions in China create value to acquiring firms? Corporate Ownership \& Control, 12(4), 117-140.

Faulkner-Bond, M., Waring, S., Forte, E., Crenshaw, R. L., Tindle, K., \& Belknap, B. (2012). Language Instruction Educational Programs (LIEPs): A Review of the Foundational Literature. Office of Planning, Evaluation and Policy Development, US Department of Education.

Frankel, M. (2015). The Biggest Mergers and Acquisitions in Banking. https://www.fool.com/investing/general/2015/04/22/thebiggest-mergers-andacquisitions-in-banking.aspx. (Retrieved on 2015/04/22)

Ghebregiorgis, F., \& Atewebrhan, A. (2016). Measurement of bank profitability, risk and efficiency: The case of the Commercial Bank of Eritrea and Housing and Commerce Bank of Eritrea. African Journal of Business Management, 10(22), 554-562.

Gupta, P. G. (2012). Mergers and Acquisitions (M\&A): The strategic concepts for the nuptials of corporate sector. Innovative Journal of Business and Management, 1, $60-68$.

Huang, J. (2010). The effects of mergers and acquisitions: Evidence from China. Dissertation and Thesis 2010: ProQuest Dissertation \& Thesis (PQPT).

Huyghebaert, N., \& Luypaert, M. (2010). Antecedents of growth through mergers and acquisitions: empirical results from Belgium. Journal of Business Research, 63(4),392-403.

Ifurueze, M.S.K. (2013). The Impact of Effective Management of Credit Sales on Profitability and Liquidity of Food and Beverage Industries in Nigeria. Double Blind Peer Reviewed International Research Journal. Vol.2 pp. 14-29

Ikpefan, O. A. (2012). Post-consolidation effect of Mergers and Acquisition on Nigeria Deposit Money Bank. European Journal of Business and Management, 4(16), 151- 162

Irfan, S., M., Nawaz, M., Zulqarnain, M. \& Khan, W. A. (2014). Do mergers and acquisitions vacillate the banks performance? (Evidence from Pakistan banking sector). Research Journal of Finance and Accounting, 5(6), 123-137.

Kemal, M. U. (2011). Post-Merger Profitability: A Case of Royal Bank of Scotland (RBS). International Journal of Business and Social Science, Vol.2 pp. 14-29

Khanal, A. R., Mishra, A. K., \& Mottaleb, K. A. (2014). Impact of Mergers and Acquisitions on Stock Prices: The U.S. Ethanol-based Biofuel Industry. Biomass and Bioenergy, 138-145. https://doi.org/10.1016/j.biombioe.2013.12.004.

Kithitu, J. (2012). Role of Mergers and Acquisitions on the Performance of Commercial Banks in Kenya. International Journal of Management and Business Studies, 1-17. 
Kyei-Poku, I. A. (2013). Impact of employee merger satisfaction on organizational commitment and turnover intentions: a study of a Canadian Financial Institution.

La Rosa, F., Bernini, F., \& Mariani, G. (2018). Diversified, integrated and cross-border acquisitions and firm performance: A comparison of family and non-family Italian listed firms. Corporate Ownership \& Control Journal, 16(1), 72-86.

Li, H., Le, L. P. and Zhang, Q. (2016). An Empirical Analysis of the Effects of Horizontal Mergers and Acquisitions on the Performance of Chinese Listed Companies-The Case of the 2008 Global Financial Crisis. Annals of Management Science, $3(2), 4$.

Liargovas, P., \& Repousis, S. (2011). The impact of mergers and acquisitions on the performance of the Greek banking sector: An event study approach. International Journal of Economics and Finance, 3(2), 89-100.

Mahesh, R. \& Prasad, D. (2012). Post-Merger and Acquisition Financial Performance Analysis: A Case Study of Select Indian Airline Companies. International journal of engineering and management sciences, 3(3)362-369.

Marfo, I. O. \& Agyei, S. K. (2013). Mergers \& Acquisition and Firm Performance: Evidence from the Ghana Stock Exchange. Research Journal of Finance and Accounting, 4(7), 99-108

Maverick, J.B. (2018). Key Financial Ratios to Analyze Retail Banks. Article from Investopedia published on 15 ${ }^{\text {th }}$ October 2018. Journal, 1-13.

Mwangi, S. W. (2014). The effect of mergers and acquisitions on the financial performance of Commercial Banks in Kenya (Doctoral dissertation, University of Nairobi).

Njambi, F. N. U., \& Kariuki, P. W. O. (2018). Effect of mergers and acquisitions on financial performance of financial institutions in Kenya. International Academic Journal of Economics and Finance, 3(1), 64-79.

Palepu, K. G., Healy, P. M., Wright, S., Bradbury, M., \& Coulton, J. (2020). Business analysis and valuation: Using financial statements. Cengage AU.

Rao, K.R.M. \& Lakew, T.B. (2012). Determinants of profitability of commercial banks in a developing country: Evidence from Ethiopia. International Journal of Accounting and Financial Management Research, 2(3), 1-20.

Sinha, N., Kaushik, K. P. \& Chaudhary, T. (2010). "Measuring post merger and acquisition performance: An investigation of select financial sector organizations in India", International Journal of Economics and Finance, Vol. 2 No. 4, pp. 190-200.

Sufian, F. (2011). Profitability of the Korean banking sector: Panel evidence on bank-specific and macroeconomic determinants. Journal of Economics and Management, 7(1), 43-72.

Terraza, V. (2015). The effect of bank size on risk ratios: Implications of banks' performance. Procedia Economics and Finance, 30, 903-909

Ullah, O., Ullah, S. \& Usman, A. (2010). "Post-merger performance of Atlas Investment and Al-Faysal Investment Bank Ltd. in Pakistan." International Research Journal of Finance and Economics, Vol. 60, pp. 168-74.

Uwizeye, E. (2016). Effect of mergers and acquisitions on organizational performance. A case of Development Bank of Rwanda.

(Doctoral dissertation, University of Rwanda) 